\title{
Network Communication Problem
}

National Cancer Institute

\section{Source}

National Cancer Institute. Network Communication Problem. NCI Thesaurus. Code C139488.

Communications problems between devices within a network system. 